UDK 528.52

\title{
BASIC CONSTRUCTION OF THE FLAT ANGLE CALIBRATION TEST BENCH FOR GEODETIC INSTRUMENTS
}

\author{
Domantas Bručas ${ }^{1}$, Vytautas Giniotis ${ }^{2}$, Petras Petroškevičius ${ }^{2}$ \\ ${ }^{1}$ Dept of Geodesy and Cadastre, ${ }^{2}$ Institute of Geodesy, Vilnius Gediminas Technical University, \\ Sauletekio al. 11, LT-10223 Vilnius, Lietuva, \\ e-mail:gi@ap.vtu.lt
}

Received 2001 2006, accepted 09062006

\begin{abstract}
In our days precise geodetic instruments are very widely used in geodesy, building structures, surveying, machine engineering etc. Many of those instruments are based on precise measurement of the directions differences (ie measurement of angles). Such instruments are: theodolites, digital theodolites, total stations etc. Testing and calibration of these instruments is quite complicated task, although it is evidently needed. In this paper we present the creation and preliminary research of accuracy of the test bench designed to perform the testing and calibration of such geodetic instruments.
\end{abstract}

Keywords: circular scale, measurement, evaluation, accuracy, uncertainty.

\section{Introduction}

In geodesy, surveying, machine engineering and other branches of industry there are very widely used instruments that allow precise planar angle measurements. Such instruments are theodolites, digital theodolites, total stations etc. As all other measuring instruments they must be tested and calibrated.

Testing these instruments worldwide is regulated by ISO 17123-3 [1] and ISO 17123-5 [2]. According to the standards an accuracy of the angle measurement performed by the instrument must be tested in the field conditions using the known length reference measure (triangulation principle). Using such a method it is possible to get only a very restricted number of angular measurements; it does not allow collecting a large number of different (desired) tested angular values. On the other hand, the tested geodetic instruments display a vast number of discrete values on their display unit during measurement, and these values must also be checked [3].

The calibration of the geodetic measuring instruments requires a large number of angular values to be compared with the reference values. Such a procedure due to its technical complexity is not regulated by any standard in Europe at all. Very few test rigs are used allowing to perform the complex testing and calibration of planar angle for geodetic instruments [4]. Those devices are usually operated by the companies - manufacturers of the measurement equipment and are not available for the wide public and the users.

It is obvious that the test bench must be developed capable of performing the geodetic instruments planar angle testing and calibration. In this paper we present the construction of the test bench for planar angle calibration and preliminary results of accuracy measurements of geodetic instruments.

\section{Calibration of the geodetic instruments}

There are several methods of angle measuring devices calibration by comparison with the reference angles. These angles can be produced by different types of measuring devices; such devices are presented in Table $1[3,5,6]$.

The first of the methods presented is based on the precise multiangular prism - polygon [7, 8]. Usually it has from 12 up to 72 flat mirrors positioned at a very precise constant angle to each other, the polygon usually being turned to a certain position together with the object to be measured and the angle of rotation is registered by the

Table 1. Technical specifications of angle measuring devices

\begin{tabular}{|c|l|c|c|c|}
\hline No & $\begin{array}{l}\text { Angle standards of } \\
\text { measure }\end{array}$ & Discretion & $\begin{array}{l}\text { Standard } \\
\text { deviation }\end{array}$ & Bias \\
\hline 1 & $\begin{array}{l}\text { Polygon } \\
\text { autocollimator }\end{array}$ & $\begin{array}{r}10^{\circ} ; 15^{\circ} ; \\
30^{\circ}\end{array}$ & $0.15^{\prime \prime}$ & $0.30^{\prime \prime}$ \\
\hline 2 & $\begin{array}{l}\text { Moore's 1440 } \\
\text { precision index }\end{array}$ & $15^{\prime}$ & $0.04^{\prime \prime}$ & $\pm 0.1^{\prime \prime}$ \\
\hline 3 & $\begin{array}{l}\text { Circular scale- } \\
\text { microscope }\end{array}$ & $\begin{array}{l}3^{\circ}, \\
4^{\circ},\end{array}$ & $0.2^{\prime \prime}$ & $\sim 3^{\prime \prime}$ \\
\hline 4 & $\begin{array}{l}\text { Photoelectric } \\
\text { rotary encoders }\end{array}$ & $5^{\circ \prime} ; 0.1^{\prime \prime}$ & $\sim 0.3^{\prime \prime}$ & $\sim 1^{\prime \prime}$ \\
\hline
\end{tabular}


optic instrument - autocollimator. Such a method is very widely applied in measuring technique and in geodesy instrumentation as well. This method has one shortcoming - the discretion of this method is very great, so it is possible to check only a small number of values offered by the calibrating measuring instrument.

The second method presented in Table 1 uses a very precise tool - Moore's 1440 Precision Index [3, 5]. It is an angular measuring device consisting of two serrated plates joined together to create the angle standard of measure. When measuring the upper disk of the Index is lifted, the lower part rotates with the object to be measured; after that the upper part is lowered back and the readings are taken. According to many sources the method is of high precision - 0,004" (Table 1). Although it has also some shortcomings - it is very difficult to automate; also during the lifting of the table (which is a necessary technological operation of the method) the calibrated instrument may loose its stability, move and unexpected errors may occur.

The third method is a classical one both in geodesy and in general technology [5, 9-11]. This method has been very widely used in the past and it requires a highly accurate circular scale and one or more (depending on the measuring method) microscopes (preferably photoelectrical) for the scale readings. The major shortcoming of the method is the need of a circular scale of very high accuracy; the scale must be of a large diameter for placing the photoelectric microscopes, it needs a precise manufacturing and a time consuming calibration. Due to a great cost of such processes this method slowly vanishes from the common use being replaced by the rotary encoders.

The fourth method presented is the most widely spread one nowadays, it uses the digital rotary encoders as the reference measure. Using modern high accuracy digital rotary encoder it is possible to achieve a very good result comparable with the classic methods. Using rotary encoders also allows reducing the size of the test bench to minimum and good possibilities for its automation.

Presently a very modern method of angle measurement has been developed using the "ring laser" as reference measure of angle. The device consists of the split laser beam which rotates into opposite directions and the angle measurement is performed by the comparison of the split beams phase difference, in this way a very high precision is being achieved. This method is slowly taking its place in technique due to its dynamic nature, by now it was mostly widely used in the aircraft navigation systems etc..

To use the described angle measuring methods for calibrating and testing the geodetic instruments their accuracy must be higher than the accuracy of the instruments being calibrated [5-7]. Standard deviations of the horizontal angle measurement of the most commonly used electronic tacheometers are listed in Table 2. Assuming the technical specifications of the most commonly used geodetic instruments, it can be considered that all the angle measuring methods listed in Table 1 could be used for their calibration and testing, the difference only being in more or less suitable ones for this task.
Table 2. Technical specifications of the most commonly used electronic tacheometers

\begin{tabular}{|c|c|}
\hline Instrument model & $\begin{array}{c}\text { Standard deviation of } \\
\text { the angle } \\
\text { measurement }\end{array}$ \\
\hline \multicolumn{2}{|l|}{ Leica } \\
\hline Leica TC@707 & 7" \\
\hline Leica TC605; TC@705 & $5 "$ \\
\hline Leica TC805; TC@703 & 3" \\
\hline Leica TPS 1201 & $1 "$ \\
\hline Leica TCA 1800 & $1 "$ \\
\hline Leica TCA2003 & $0.5^{\prime \prime}$ \\
\hline \multicolumn{2}{|l|}{ Trimble } \\
\hline Trimble $3303 ; 5603$ & 3" \\
\hline Trimble $3305 / 6$ & $5 "$ \\
\hline Trimble 5601 & $1 "$ \\
\hline Trimble $5602 ; 5602$ DR300 & $2 "$ \\
\hline Trimble S6 & $1 "$ \\
\hline \multicolumn{2}{|l|}{ Sokkia } \\
\hline $\begin{array}{l}\text { Sokkia SET500; SET4C/SET4B; } \\
\text { Sokkia SET5F }\end{array}$ & $5 "$ \\
\hline Sokkia SET600 & $6 "$ \\
\hline Sokkia SET2C/SET2B & $2 "$ \\
\hline Sokkia SET3C/SET3B & $3 "$ \\
\hline Sokkia SET6F & $7 "$ \\
\hline \multicolumn{2}{|l|}{ Topcon } \\
\hline Topcon GTS6A/6B & $2^{\prime \prime}-5^{\prime \prime}$ \\
\hline Topcon GTS1 & $20 "$ \\
\hline \multicolumn{2}{|c|}{ Hewlett-Packard } \\
\hline 3820A Elect.Total St. & $2 "$ \\
\hline
\end{tabular}

\section{Construction of the angle calibration test rig}

At Vilnius Gediminas Technical University, Institute of Geodesy a test rig capable of testing and calibrating the planar angles measuring geodetic devices has been constructed. A high-precision circular scale dividing machine was applied as a base for such equipment.

The machine consists of an artificially eldered stable base where high-precision pure rolling bearings were mounted, the rotary disks fitted with the circular scale on it [7]. The machine was powered electro-mechanically by means of warm gear with the gearing $1 / 1080$.

For the angle calibration purposes the machine was considerably modified, the principal diagram of it is shown in Fig 1. The precise rotary encoder (produced by "Brown \& Sharpe-Precizika") (2) was fitted to control the rotation angle, the original worm gear being fitted with the step motor (3) controlled by the computer (1), the control unit and the controlling programmes were created. Also there were some minor changes made such as fitting of the 12 angle polygon (4) in the centre of the rotary disk, allowing at the same time an attachment of the electronic tacheometer (6). The photoelectric autocollimator (4) and photoelectric microscopes (5) placed on the circular scale were also attached to further controlling the angular position of the disk.

The mode of the test rig operation is pretty basic - the rotary table (disk) using the worm gear and the step motor controlled by the computer rotates to a certain desired angle controlled by the rotary encoder; after it reaches the needed angle and stops. So the table can be positioned with the discretion of $0,001^{\circ}$. The angle position is measured by photoelectric microscopes applying the circular scale. The 


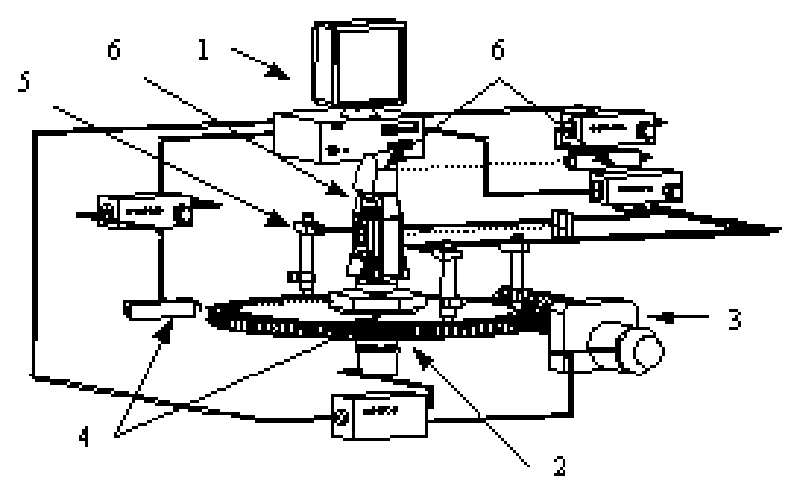

Fig 1. General diagram of the test rig

photoelectric autocollimator is pointed at the multiangular prism - polygon and the discretion of these measurements are $30^{\circ}$.

The geodetic instrument - electronic tacheometer is attached to the rotary table by its base and so it rotates together with the table. The upper part of the tacheometer is loosely supported by the basic part of the test rig and so it stands still. Since it is very difficult to hold the upper part in an absolutely constant position, so for achieving good measuring results the tacheometer at every measuring stop is being manually pointed to a certain mark.

The measuring methods using a rotary encoder, autocollimator and polygon, circular scale and microscopes combined in one equipment can perform the measurements both independently and in the united system. Such a composition of measuring methods allows monitoring constantly the performance of each measuring device and performing the self calibration of each component of the system. The multiangular prism autocollimator system is considered as the reference angle and all other measuring systems are being compared to it.
The system makes a full calibration turn $\left(360^{\circ}\right)$ in approx $30 \mathrm{~min}$.

The preliminary measurements results under repeatability conditions (the same day, same operator etc) are presented in Table 2.

Every point at $i^{\text {th }}$ angular position accuracy of the instrument is calculated as

$$
\delta \varphi_{t i}=\frac{1}{n}\left[\sum_{i=1}^{n}\left(\Delta \varphi_{t_{j} i}-\Delta \varphi_{t_{j} 0}\right)-\sum_{i=1}^{n}\left(\Delta \varphi_{a_{j} i}-\Delta \varphi_{a_{j} 0}\right)\right],
$$

where $\Delta \varphi_{t_{j} i}-$ tacheometer readings, $\Delta \varphi_{a_{j} i}-$ autocollimator - polygon readings, $j-$ number of times of the full circle measurement cycles performed, it usually is equal to 3 or 5 .

The readings from the microscope - scale are calculated in the same way, thus enabling to use it as reference measure for further geodetic instrument calibration.

Some statistical characteristics are calculated during the results evaluation and determination of the measurand, that is, an estimate of the standard deviation $S$ at the $t$-test of Student and degrees of freedom $n$. This is used for the final determination of systematic part (bias) of angular error with the uncertainty $\varepsilon$. Some results of measurements by electronic tacheometer "Wild Theodomat T1000" are in Table 3, Figs 2-5.

The presented system although have some shortcomings, mostly due to the equipment imperfection. The largest of those is naturally too small a precision of the rotary encoder which is the basic measurement device in the test rig. It is obvious that the encoder must be replaced with a more precise one, having also a smaller discretion. Even at the first measurement tests it became clear that the circular scale of the rotary table had a great bias in some areas.

Table 3. Preliminary test results

\begin{tabular}{|c|c|c|c|c|c|c|c|c|c|c|c|c|c|c|c|c|}
\hline & \multicolumn{3}{|c|}{ Test 1} & \multicolumn{3}{|c|}{ Test 2} & \multicolumn{3}{|c|}{ Test 3} & \multicolumn{3}{|c|}{ Test 4} & & & & \\
\hline 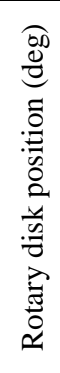 &  & 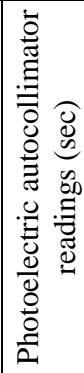 & 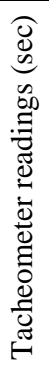 & 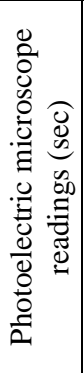 & 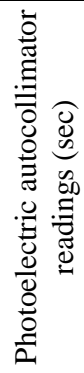 & 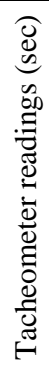 &  & 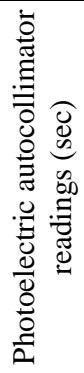 & 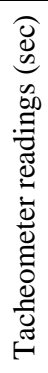 & 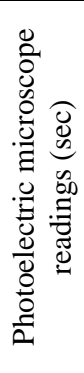 & 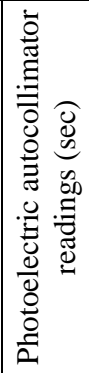 & 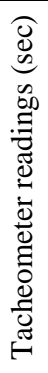 & 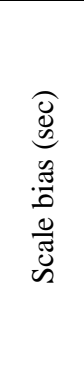 & 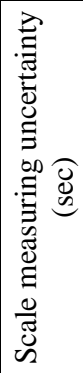 & 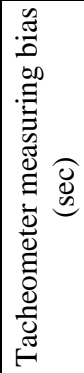 & 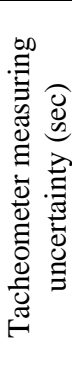 \\
\hline 0 & 0,0 & 0,0 & 3 & 0,0 & 0 & 0 & 0,0 & 0 & 3 & 0,0 & 0 & 0 & 0,00 & 0,000 & 1,50 & 1,21 \\
\hline 30 & 35,5 & 6,6 & 2 & 31,4 & 0,5 & -3 & 43,5 & 13,3 & 2 & 31,1 & 0,4 & 1 & 30,20 & 0,627 & $-4,70$ & 3,44 \\
\hline 60 & 37,0 & 6,6 & 4 & 34,2 & 1 & -3 & 41,7 & 10,3 & 1 & 34,5 & 0,6 & 0 & 32,23 & 1,132 & $-4,12$ & 2,59 \\
\hline 90 & 44,3 & 9,8 & 2 & 43,8 & 8,7 & 1 & 49,4 & 13,7 & 0 & 38,1 & 4,2 & 2 & 34,77 & 0,537 & $-7,85$ & 3,27 \\
\hline 120 & 32,1 & 3,7 & 2 & 35,9 & 6 & -2 & 37,9 & 7 & 0 & 33,9 & 4,2 & 4 & 29,72 & 0,711 & $-4,22$ & 2,69 \\
\hline 150 & 32,3 & 0,0 & 0 & 28,4 & $-5,8$ & -1 & 32,3 & $-1,2$ & 1 & 34,1 & 0,9 & 1 & 33,30 & 0,548 & 1,78 & 1,57 \\
\hline 180 & 35,7 & 2,7 & 2 & 37,6 & 2,4 & -1 & 39,2 & 6,1 & 1 & 37,7 & 3,9 & 3 & 33,78 & 0,715 & $-2,53$ & 1,47 \\
\hline 210 & 33,4 & 3,8 & 2 & 30,0 & $-2,6$ & -2 & 34,3 & 2,2 & 1 & 35,3 & 5,2 & 1 & 31,12 & 1,012 & $-1,65$ & 1,38 \\
\hline 240 & 33,0 & $-1,4$ & 2 & 35,5 & $-3,1$ & -1 & 38,2 & 1,6 & 1 & 32,3 & $-2,4$ & 0 & 36,08 & 1,340 & 1,83 & 1,19 \\
\hline 270 & 20,7 & $-11,2$ & 3 & 22,5 & -11 & -2 & 24,8 & $-7,9$ & 0 & 21,5 & $-9,8$ & 1 & 32,35 & 0,668 & 10,48 & 1,92 \\
\hline 300 & 20,5 & $-11,2$ & 2 & 25,3 & $-9,8$ & -2 & 23,7 & $-9,8$ & 1 & 21,4 & $-10,4$ & 1 & 33,02 & 1,124 & 10,80 & 1,57 \\
\hline 330 & 17,3 & $-11,2$ & 1 & 12,7 & $-18,1$ & -3 & 16,9 & $-12,7$ & 3 & 13,7 & $-15,9$ & 0 & 29,61 & 0,656 & 14,73 & 1,20 \\
\hline 360 & $-2,5$ & $-2,3$ & 0 & 2,2 & 0,3 & -3 & 3,2 & 1,8 & 3 & 2,2 & 1,9 & 3 & 0,83 & 0,673 & 0,33 & 1,73 \\
\hline
\end{tabular}




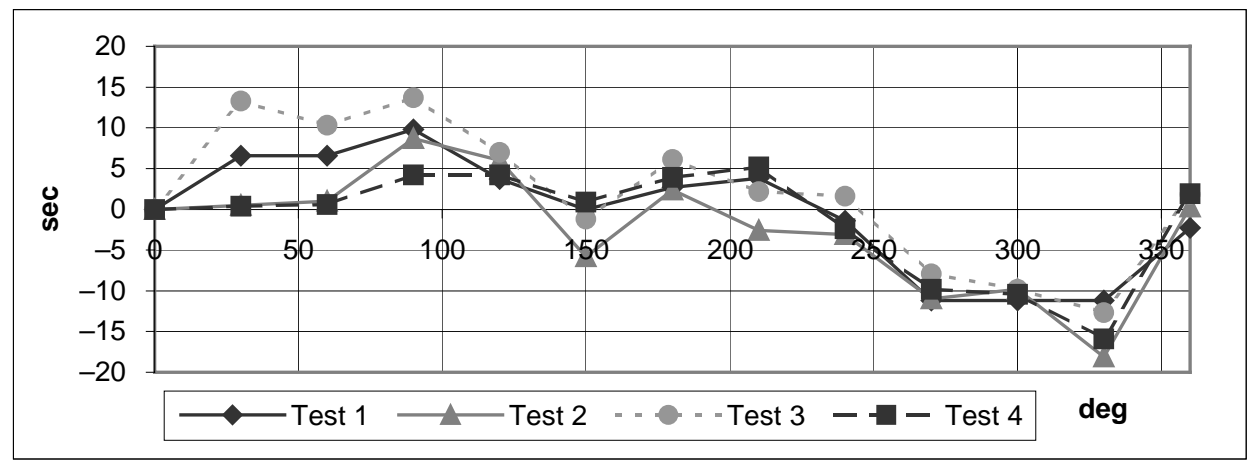

Fig 2. Graphs of readings from the photoelectric autocollimator (20 02 2006)

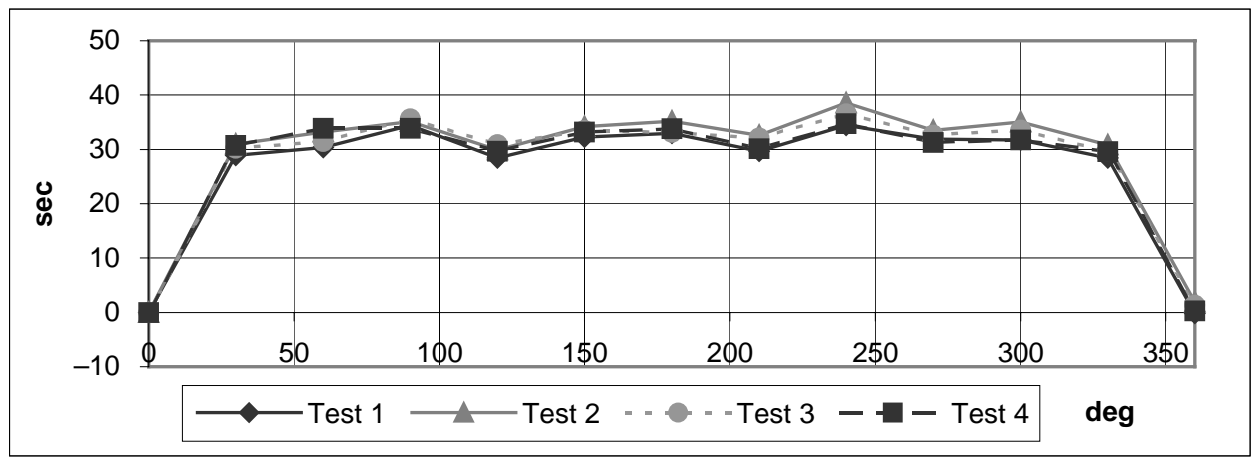

Fig 3. Graphs of the circular scale errors (20 02 2006)

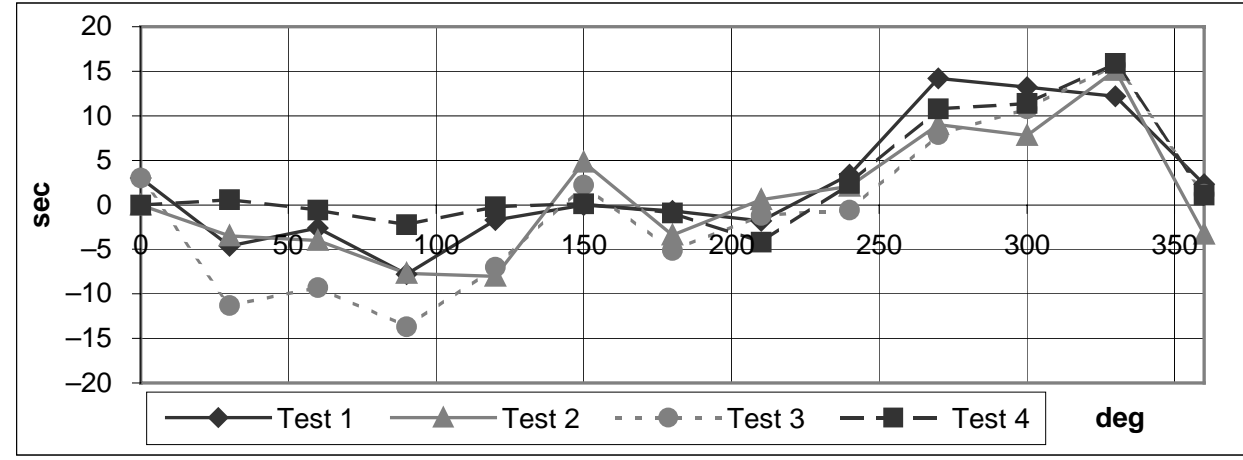

Fig 4. Graphs of the tacheometer readings errors (20 02 2006)

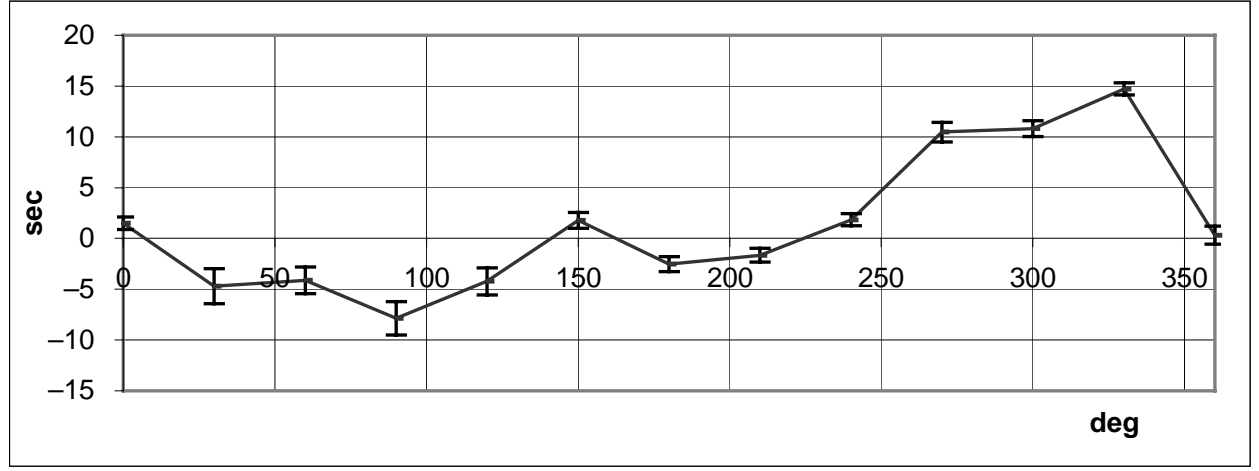

Fig 5. Graph of the tacheometer readings with uncertainty (20 02 2006)

This might be due to some errors during circular scale's strokes cutting. Although the scale bias can be eliminated, it is very time consuming process requiring a significant experimental study of each stroke of the scale.
Some additional difficulties occur when pointing the tacheometer to a certain target. Till now it was tried to point the tacheometer manually but, as it can be seen from the results, manual pointing does not give an appropriate precision also interfering of the 
operator into the machine work considerably slows down the calibration process. It's planned to construct an automatic pointing device witch would consist of photoelectric autocollimator fixed on the non-moving part of the test rig and the mirror mounted on the tacheometer (Fig 1) [6]. In that way the tacheometer would be roughly pointed to a target (same as it is performed now) and the precise position of the geodetic device would be obtained by comparing the tacheometer readings with the autocollimator data. The calibration process would be not interrupted (data of the autocollimator deriving automatically) and the method would allow eliminating the tacheometer mounting eccentricity bias.

At present the test rig is being tested and further modified to achieve better results.

\section{Conclusions}

- Practice of testing geodetic measurement devices using the measure of length does not allow testing and calibration of the wide range of discrete angle values which features a geodetic instrument. For this purpose a special test rig must be applied.

- The device for geodetic instruments horizontal angle calibration has been constructed and was preliminary investigated.

- $\quad$ By the test rig developed the angle values may be measured by three independent measuring systems precise rotary encoder, the circular scale - photoelectric microscope and the polygon with autocollimator as the standard measure of angle; electronic tacheometer being mounted on the top.

- The test rig runs in an automatic mode and further automation of the testing and calibration process is continued.

- Preliminary measuring tests have been performed; showing that (despite quite good results) test rig needs further modification increasing an accuracy of calibration.

\section{References}

1. ISO 17123-3: Optics and optical instruments - Field procedures for testing geodetic and surveying instruments. - Part 3: Theodolites. 2001.

2. ISO 17123-5: Optics and optical instruments - Field procedures for testing geodetic and surveying instruments. - Part 5: Electronic tacheometers.

3. Giniotis, V.; Rybokas, M.; Petroškevičius, P. Investigations into the accuracy of angle calibration. Geodesy and Cartography (Geodezija ir kartografija), Vol XXX, No 3, 2004, p. 65-70.

4. Ingensan, H. A new method of theodolite calibration. In: XIX International Congress, Helsinki, Finland, 1990, p. 91-100.

5. Giniotis, V. Position and displacement measurement (Padėties ir poslinkių matavimas). Vilnius: Technika, 2005. 215 p. (in Lithuanian).

6. Jablonski, R.; Shimokohbe, A. and Nagai, A. Calibration system for precision angle standards. Bull. P.M.E. (T.I.T.), No 45, 1980, p. 17-24.

7. Just, A.; Krause, M.; Probst, R. and Wittekopf, R. Calibration of high-resolution electronic autocollimators against an angle comparator. Metrologia, Vol 40, 2003, p. $288-294$.
8. Yandayan, T. Application of the novel technique for calibration of 23 sided polygon angles with non-integer subdivision of indexing table. In: $8^{\text {th }}$ Intern Symposium on Measurement and Quality Control in Production, Düsseldorf, 12-15 October 2004, p. 769-774.

9. Giniotis, V. Brief review of methods for measuring of circular scales. Geodesy and Cartography (Geodezija ir kartografija), No 2 (26). Vilnius: Technika, 1997, p. 2125.

10. Jelisejev, S. V. Geodetic instruments and devices. Basic principles of design, calculations and production features. Moscow: Nedra, 1973. 392 p. (in Russian).

11. Rybokas, M.; Giniotis, V.; Petroškevičius, P.; Kulvietienè, R.; Bručas, D. Performance and accuracy monitoring of geodetic instruments. In: Proceedings of the Intern Conf on Condition Monitoring held at Kings

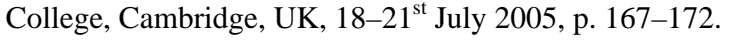

\section{Domantas Bručas, Doctoral student.}

Vilnius Gediminas Technical University. Dept of Geodesy and Cadastre ( $\mathrm{Ph}+3705274$ 4703, Fax +370 5274 4705).

Author of four scientific papers. In 2005 visited Institut für Geodäsie und Photogrammetrie, Eidgenössische Hochschule Zürich (Switzerland) under the grant of Gerbert Ruf Foundation.

Research interests: development and investigation of comparator for angular measurements, automation of the processing the measurement results.

\section{Vytautas Giniotis, Prof, Doctor Habil. \\ Vilnius Gediminas Technical University. Institute of Geodesy (Ph +370 5274 4705, Fax +370 5274 4705). \\ Author of one monograph and more than 160 scientific papers. Participant of many intern conferences, research and lecturing visits to Germany, Austria and UK universities. \\ Research interests: 3D measurements and instrumentation, automation of measurements, angular measurements.}

\section{Petras Petroškevičius, Professor, Doctor Habil.}

Vilnius Gediminas Technical University. Dept of Geodesy and Cadastre (Ph, Fax +370 5274 4705), e-mail: gi@ap.vtu.lt.

Author of 1 monograph and more than 100 scientific publications. Participated in many intern conferences.

Research interests: determination of Earth satellites orbits, research of Earth gravity field by means of satellite geodesy and gravimetric methods, establishment of geodetic and gravimetric networks.

\section{STENDO GEODEZINIŲ PRIETAISŲ PLOKŠČIAJAM KAMPUI KALIBRUOTI BAZINE் KONSTRUKCIJA}

\section{Bručas, V. Giniotis, P. Petroškevičius}

$\mathrm{S}$ a n tra u k

Pastaruoju metu tikslūs geodeziniai prietaisai yra plačiai naudojami geodezijoje, statyboje, topografijoje, mašinu gamyboje ir t. t. Daugumos šiu prietaisu veikimo principas pagrisstas tiksliu kampu matavimu. Tokie prietaisai teodolitai, elektroniniai tacheometrai ir kt. Atlikti šių prietaisu patikrą ir kalibruoti - gana sudètingas techninis uždavinys. Aprašomas naujai sukurtas irenginys tokiems geodeziniams prietaisams kalibruoti ir tikrinti, jo kūrimo eiga bei pradiniai tikslumo tyrimai.

Prasminiai žodžiai: apskritiminè skalè, matavimas, pakilimas, tikslumas, neapibrěžtis. 